\section{Use of Mytilus edulis biosentinels to investigate spatial patterns of norovirus and faecal indicator organism contamination around coastal sewage discharges}

Winterbourn, James; Clements, Katie; Lowther, James A.; Malham, Shelagh; McDonald, James; Jones, David

\section{Water Research}

\author{
DOI: \\ 10.1016/j.watres.2016.09.002
}

Published: 15/11/2016
\end{abstract}

Peer reviewed version

Cyswllt i'r cyhoeddiad / Link to publication

Dyfyniad o'r fersiwn a gyhoeddwyd / Citation for published version (APA):

Winterbourn, J., Clements, K., Lowther, J. A., Malham, S., McDonald, J., \& Jones, D. (2016).

Use of Mytilus edulis biosentinels to investigate spatial patterns of norovirus and faecal indicator organism contamination around coastal sewage discharges. Water Research, 105(November), 241-250. https://doi.org/10.1016/j.watres.2016.09.002

\footnotetext{
Hawliau Cyffredinol / General rights

Copyright and moral rights for the publications made accessible in the public portal are retained by the authors and/or other copyright owners and it is a condition of accessing publications that users recognise and abide by the legal requirements associated with these rights.

- Users may download and print one copy of any publication from the public portal for the purpose of private study or research.

- You may not further distribute the material or use it for any profit-making activity or commercial gain

- You may freely distribute the URL identifying the publication in the public portal ?
}

Take down policy

If you believe that this document breaches copyright please contact us providing details, and we will remove access to the work immediately and investigate your claim. 
1 Use of Mytilus edulis biosentinels to investigate spatial patterns of norovirus and faecal

2 indicator organism contamination around coastal sewage discharges

3

4 James B. Winterbourn ${ }^{\mathrm{a},{ }^{*}}$, Katie Clements $^{\mathrm{b}}$, James A. Lowther ${ }^{\mathrm{c}}$, Shelagh K. Malham ${ }^{\mathrm{b}}$, James E.

$5 \quad$ McDonald $^{\mathrm{d}}$, Davey L. Jones ${ }^{\mathrm{a}}$

6

7 a School of Environment, Natural Resources \& Geography, Bangor University, Bangor, Gwynedd,

$8 \quad$ LL57 2UW, UK

$9 \quad{ }^{\mathrm{b}}$ School of Ocean Sciences, Bangor University, Bangor, Gwynedd, LL59 5AB, UK

$10 \quad{ }^{\mathrm{c}}$ CEFAS, The Nothe, Barrack Road, Weymouth, Dorset, DT4 8UB, UK

$11{ }^{\mathrm{d}}$ School of Biological Sciences, Bangor University, Bangor, Gwynedd, LL57 2UW, UK

12

13 *Corresponding author: Environment Centre Wales, Bangor University, Deiniol Road, Bangor, 14 Gwynedd, LL57 2UW, UK.

15 E-mail address: benwinterbourn@ gmail.com (Ben Winterbourn) 


\section{ABSTRACT}

Bivalve shellfish have the capacity to accumulate norovirus (NoV) from waters contaminated with human sewage. Consequently, shellfish represent a major vector for NoV entry into the human food chain, leading to gastrointestinal illness. Identification of areas suitable for the safe cultivation of shellfish requires an understanding of NoV behaviour upon discharge of municipal-derived sewage into coastal waters. This study exploited the potential of edible mussels (Mytilus edulis) to accumulate $\mathrm{NoV}$ and employed the ISO method for quantification of NoV within mussel digestive tissues. To evaluate the spatial spread of NoV from an offshore sewage discharge pipe, mesh cages of mussels were suspended from moorings deployed in a $9 \mathrm{~km}^{2}$ grid array around the outfall. Caged mussels were retrieved after 30 days and NoV (GI and GII), total coliforms and E. coli enumerated. The experimentally-derived levels of NoV GI and GII in mussels were similar with total NoV levels ranging from $7 \times 10^{1}$ to $1.6 \times 10^{4}$ genome copies $\mathrm{g}^{-1}$ shellfish digestive gland $(\Sigma \mathrm{GI}+\mathrm{GII})$. NoV spread from the outfall showed a distinct plume which matched very closely to predictions from the tidallydriven effluent dispersal model MIKE21. A contrasting spatial pattern was observed for coliforms (range $1.7 \times 10^{2}$ to $2.1 \times 10^{4} \mathrm{CFU} 100 \mathrm{~g}^{-1}$ shellfish tissue) and E. coli (range 0 to $1.2 \times 10^{3} \mathrm{CFU} 100$ $\mathrm{g}^{-1}$ shellfish tissue). These data demonstrate that hydrodynamic models may help inform effective exclusion zones for bivalve harvesting, whilst coliform / E. coli concentrations do not accurately reflect viral dispersal in marine waters and contamination of shellfish by sewage-derived viral pathogens.

\section{Keywords: Food safety; Marine pollution; Risk assessment; Viral contamination; Wastewater} treatment plant. 


\section{Introduction}

The overall global burden of human disease caused by sewage pollution of coastal waters has been estimated at 4 million lost person-years annually (Moore et al., 2013). Within this, consumption of bivalve molluscan shellfish contaminated with norovirus (NoV) derived from human faeces represents a well-established human health risk (Lees, 2000; Malham et al., 2014). According to the European Food Safety Authority (EFSA), production of shellfish in areas which are not faecally contaminated represents the most effective control measure for NoV (EFSA Panel on Biological Hazards, 2012). However, achieving this goal represents a major challenge to the shellfish industry due to the vast number of wastewater discharges along the European coastline and the traditional colocation of shellfish harvesting areas around estuaries and coastal communities where sewage contamination is most apparent (Fleming et al., 2006; Paraskevas et al., 2002). Although significant improvements have been made in the microbiological quality of coastal waters in Europe (Campos et al., 2013), in some regions this is being hampered by the increased pressure on the wastewater infrastructure (due to a rise in human population and extreme weather events which are increasing the volumes of untreated sewage being released into coastal waters; Matthiessen and Law, 2002; Stapleton et al., 2008). The introduction of exclusion zones around sewage discharges preventing shellfish harvesting is being considered in Europe and elsewhere, however, their delineation and social acceptability remains difficult, particularly if a quasi-zero risk of contamination is required (Dunn et al., 2014; Fitzgerald, 2014).

Traditionally, bacteria including coliforms and enterococci have been used to estimate the level of faecal contamination of water and / or shellfish (Oliveira et al., 2011; Pancorbo and Barnhart, 1992), and may be referred to collectively as Faecal Indicator Bacteria (FIB). In Europe, Escherichia coli is adopted as the traditional indicator of faecal (sewage) contamination in shellfish and is used for risk assessment and management purposes (Anon, 2004). However, studies have indicated that $E$. coli or total coliforms provides a relatively poor indicator of the potential risk of contracting illness from a wide range of human pathogenic organisms (Ferguson et al., 1996; Griffin et al., 2001; Majori 
et al., 1984). Reasons for this poor correlation include the different environmental persistence of coliforms relative to viruses, protozoa and other bacteria in marine water, and differences in their spatial and temporal discharge patterns (Fong and Lipp, 2005). In addition, E. coli may be introduced to the environment from agricultural livestock making it a poor indicator of point-source, humanderived wastewater discharges (Campos et al., 2013). Therefore, E. coli and NoV may originate from different sources, be conveyed into the marine environment via alternate routes, may be susceptible to different stresses, and may be differentially accumulated by shellfish. The current faecal indicator approach may underestimate the risk from human viruses which are introduced from inadequatelyor un-treated wastewater (De Donno et al., 2012; Fong and Lipp, 2005; Griffin et al., 1999).

Methods for direct recovery and concentration of enteric viruses from coastal waters include adsorption to and elution from charged membranes or particles, and ultrafiltration and flocculation approaches (Katayama et al., 2002; Cormier et al., 2014; Calgua et al., 2008). Complications include the need for large sample volumes and difficulties in removing PCR-inhibitory substances originating from the marine environment. Of the methods available, the best choice may depend upon specific PCR-inhibitory compounds present in samples from different locations, and the target virus (Rodriguez et al., 2012). Recently, streamlined processes giving high recoveries of Hepatitis A Virus from seawater using zeolite have been described and other studies have been able to report on the presence and levels of enteric viruses recovered directly from coastal waters using flocculation (Cormier et al., 2016; Kaas et al., 2016). However, direct recovery of viruses from environmental waters can only provide a snapshot in time. This may limit our understanding of viral pollutant flow in areas subject to intermittent discharges and/or complex tidal regimes.

Bivalve shellfish have been shown to efficiently accumulate viral particles (Asahina et al., 2009; De Donno et al., 2012; Nenonen et al., 2008) and sensitive quantitative methods which detect NoV genomes in molluscan shellfish using molecular techniques (PCR) exist (Anon, 2013; Lees and CEN WG6 TAG4, 2010). This offers the potential to use shellfish as an integrator of NoV pollution within both marine and estuarine environments. NoV levels bioaccumulated in oysters experimentally 
placed at several locations within an estuary impacted by sewage discharges have recently been presented (Campos et al., 2015). Due to their fixed location, shellfish can be employed to provide a spatial map of viral pollutant flow from point source wastewater discharges. Further, due to their fixed location, they can be employed to provide a spatial map of viral pollutant flow from point source wastewater discharges.

The position and dilution of wastewater effluent plumes has been determined using approaches such as bacterial, bacteriophage or dye tracing (Hammerstein et al., 2015). More recently, hydrodynamic models have been used to predict the spatial and temporal patterns of contamination originating from coastal discharges (Dunn et al., 2014). Such models have been parameterized to predict microbial concentrations and the potential for shellfish exposure (Gourmelon et al., 2010; Muhammetoglu et al., 2012; Riou et al., 2007). Validation of these models, however, remains critical if they are to be adopted for risk assessment purposes and coastal zone management (Gourmelon et al., 2010).

The aim of this study was to improve our understanding of NoV behaviour upon discharge of sewage into coastal waters. Our first objective was to derive and compare the spatial contamination patterns for NoV genogroups one and two (GI and GII), E. coli and total coliforms about a long sea wastewater outfall. Our second objective was to compare these field-derived spatial contamination patterns with those predicted from a tidally-driven effluent dispersal model. In lieu of EFSA advice to produce shellfish in waters which are not faecally contaminated and considering that FIB may be a poor indicator of sewage-derived viral contamination, the specific intentions were a) to detect any differences in the spatial contamination pattern for NoV, which might not be captured by the FIB approach, and b) to determine whether hydrodynamic models may offer greater potential for prediction of NoV contamination and designation of shellfish harvesting exclusion zones.

\section{Materials and methods}

\subsection{Site selection}



3.569200W; Fig. 1), which serves a total population equivalent of 77,953 people, was selected for this study. The discharge is consented for up to $38,860 \mathrm{~m}^{3} \mathrm{~d}^{-1}$ with a dry weather flow not exceeding $15,941 \mathrm{~m}^{3} \mathrm{~d}^{-1}$. Sewage released from the outfall receives only primary and secondary treatment (activated sludge) prior to discharge. Previous studies have indicated that similar activated sludge wastewater treatment plants (WWTP) may achieve reductions for NoV GI and GII concentrations of less than one $\log _{10}$ genome copy (Flannery et al., 2012; Nordgren et al., 2009). In addition to treated effluent, under high flow conditions (i.e. stormflow) there are periods when storm water is discharged untreated into marine waters via this outfall, however, no such events were recorded during the duration of this trial. In compliance with EU bathing water quality standards at proximate beaches, the outfall discharges into coastal waters of Liverpool Bay at $4 \mathrm{~km}$ offshore, in $6.9 \mathrm{~m}$ of water at Lowest Astronomical Tide. The conditions reported here are typical of many other discharge points around the European coastline. We hypothesized that these conditions could result in a significant release and persistence of potential human pathogens in marine waters. This site was also chosen as shellfish are commercially farmed on a large scale near the study area with the harvested product exported to a range of European countries.

\subsection{Sampling regime and shellfish biosentinels}

This study exploited the potential of the common (or blue) edible mussel Mytilus edulis (L.) to accumulate virions and bacterial cells from shellfish growing waters. Mytilus edulis were collected $50 \mathrm{~km}$ away from the study site. To minimize variability associated with growing conditions, animals were collected via a single short trawl $(<5 \mathrm{~m})$ of broadcast-cultivated animals from a commercial bed with a long term EU designation of Class B (i.e. 230-4600 E. coli CFU per $100 \mathrm{~g}$ of flesh) and which has a history of low level NoV contamination. The animals were washed, size graded (>45 mm) and 200 animals randomly selected for baseline enumeration of NoV and E. coli at time zero $\left(T_{0}\right)$. Ten replicate samples of 10 animals were analyzed for NoV and 10 replicate samples of $50 \mathrm{~g}$ shellfish 
flesh for total coliforms and E. coli. Seventy eight batches containing 35 live animals were then placed in individual net bags $(300 \times 300 \mathrm{~mm})$. Six net bags were then placed in each of 13 plastic cages to allow collection of one net bag from each cage at six time points of $\sim 30 \mathrm{~d}$ interval. Cages were placed in triplicate at 13 independent points in a diamond-shaped array around the wastewater outfall (Fig.

1). The cages were suspended at a sea depth of $1 \mathrm{~m}$ by attaching them to a plough anchored Polyform A3 buoy. The individual sample points were separated by $1 \mathrm{~km}$ in $\mathrm{x}$ and $\mathrm{y}$ dimensions. The cages were deployed in March when NoV community outbreaks were close to maximal (PHE, 2016) and the first samples were recovered $30 \mathrm{~d}$ later in April, 2012.

\subsection{Quantification of norovirus in mussels}

NoV quantification in mussel digestive tissue was determined by quantitative reversetranscription PCR (qRT-PCR) in accordance with the approved method of the European Committee for Standardization (CEN) (Lees and CEN WG6 TAG4, 2010; Lowther et al., 2012a). Briefly, tissue homogenates were prepared by Proteinase $\mathrm{K}$ digestion of a $2 \mathrm{~g}$ aliquot of pooled digestive glands dissected from 10 animals and after the addition of Mengovirus $\mathrm{vMC}_{0}$ as an extraction control. RNA extraction was performed with a Nuclisens miniMAG ${ }^{\circledR}$ and magnetic extraction reagents (bioMérieux Inc., Durham, NC) following the manufacturer's protocol. The positive controls were derived from homogenates prepared as per the samples but after addition of 1 Lenticule ${ }^{\circledR}$ disc of Norovirus Reference Material for each genogroup (Public Health England, London, UK) to ten digestive glands. The animals used for the positive controls originated from extra mesh bags placed within the experimental cages. One-step qRT-PCR for Mengovirus (extraction control) and for both NoV genogroups, including plate layout, and reaction mixes, were performed exactly as described by Lowther et al. (2012a) except for the genogroup II assay where TAMRA was used as the quencher. The thermocycler used was an Applied Biosystems 7900HT (Life Technologies Ltd, Paisley, UK). The use and treatment of a suite of qRT-PCR controls and all quantification steps also followed the same methods of Lowther et al. (2012a). Three aliquots of extracted RNA per sample were tested in 
each NoV genogroup-specific qRT-PCR assay, average quantities from three replicates giving overall quantity in detectable genome copies $\mathrm{g}^{-1}$ digestive gland $\left(\mathrm{gc} \mathrm{g}^{-1}\right)$. Extraction efficiency and RT-PCR efficiency/inhibition were assessed using Mengovirus $\mathrm{vMC}_{0}$ and RNA external controls, respectively. Retesting was undertaken according to action thresholds for extraction and RT-PCR efficiencies of $1 \%$ and $25 \%$ respectively or due to failed positive/negative PCR controls. No adjustment for losses during processing or RT-PCR inhibition was made (uncorrected). This system was in agreement with the principles outlined in the draft Technical Specification developed by the joint CEN/ISO working group for standardization of methods for detection of viruses in foodstuffs (Lees and CEN WG6 TAG4, 2010).

\subsection{Quantification of E. coli and coliforms in mussels}

Culture methods were used for determination of bacterial Colony Forming Units (CFU) in line with the European Union Shellfish Water Directive (EU, 2006). Bacterial colony forming units were enumerated from shellfish flesh by direct plating onto selective agar as described in Clements et al. (2013). Briefly, mussel samples were washed with sterile seawater to remove any residual sediment, debris and encrusting organisms before swabbing with $100 \%$ methanol to remove the shell surface biofilm. Samples were left for approximately $15 \mathrm{~min}$ to allow the methanol to fully evaporate. Mussels were opened aseptically and $50 \mathrm{~g}$ of flesh and intra-valvular fluid was obtained. Samples were homogenized for $60 \mathrm{~s}$ at 10,000 rev $\min ^{-1}$ using a Bamix ${ }^{\circledR}$ blender (Seal Rock Enterprises Ltd., Bishops Stortford, UK). From the resulting homogenate, $200 \mu \mathrm{l}$ was plated onto Brilliance ${ }^{\circledR}$ selective agar (\#CM0956; Oxoid Ltd, Basingstoke, UK) to determine E. coli and coliform counts. All plates were inverted and incubated at $37^{\circ} \mathrm{C}$ and bacterial CFU enumerated after $24 \mathrm{~h}$.

\subsection{Statistical analysis}

To ensure our data are comparable with survey data generated by the UK government National Reference Laboratory (Lowther et al., 2012a), samples returning “not detected” results for a particular 
195

NoV genogroup were assigned a score of $20 \mathrm{gc} \mathrm{g}^{-1}$ for that genogroup (half the limit of detection; LOD). Samples giving positive results below the limit of quantification (LOQ; $100 \mathrm{gc} \mathrm{g}^{-1}$ ) were assigned a score of $50 \mathrm{gc} \mathrm{g}^{-1}$. Statistical analysis was carried out using SPSS Statistics v20 (IBM Corp., Armonk, NY) while geostatistical analysis was carried out in ArcGIS v9.3.1 (ESRI Inc., Redlands, CA) using the spline method in the Spatial Analyst toolbox.

\subsection{Hydrodynamic modelling}

The Danish Hydraulic Institute (DHI) MIKE21 AD/HD hydrodynamic and water quality model was used to describe the dispersion of the effluent plume from the offshore outfall (DHI, 2003; DHI, 2011; Ekebjærg and Justesenu, 1991; Siegle et al., 2007). We chose this model due to its extensive use for simulating hydrodynamics, water quality, wave dynamics and related processes in UK coastal areas (Babu et al., 2005; Davies et al., 2009; Williams et al., 2014). The model is also used as part of the Bathing Water Compliance Assessment undertaken by Intertek Energy and Water Consultancy Services for this stretch of coastline on behalf of Welsh Water. The model had a resolution of $45 \times 45 \mathrm{~m}$ and encompassed $600 \times 400$ such cells. The model simulation was undertaken for a 3 day period, run under a calm wind scenario, with a model time step of $60 \mathrm{~s}$ and an output timestep of $10 \mathrm{~min}$. The model predicted the effluent plume dispersal of a $1 \mathrm{~m}^{3} \mathrm{~s}^{-1}$ discharge released continuously over $12 \mathrm{~h}$ at a concentration typical of crude sewage $\left(1 \times 10^{6}\right.$ pathogen $\left.\mathrm{units}^{-1}\right)$. No microbiological decay rate was used in the model to describe loss of cell viability, instead it was run as a conservative microbiological pollutant. We considered this appropriate for our purposes as NoV exhibits moderate persistence in UK coastal waters (Dancer et al., 2010). The sum concentration of pathogen in each grid cell over the model run was recorded and graphically presented (i.e. total number of pathogen units predicted to pass through a cell over a model run). Therefore the measure is an amalgamation of all the modelled timesteps and does not denote a moment in time. The summed concentration for specific model cells (i.e. where our experimental moorings were located) was extracted and used as a predictor of relative exposure to contaminants originating from the plume. 


\section{Results}

\subsection{Baseline microbiological contaminant levels}

Baseline levels for NoV GI and GII, E. coli and coliforms in mussels used to stock the experimental cages at $T_{0}$ are shown in Table 1. Overall, the levels of NoV GII were very similar between the replicate batches $(\mathrm{CV}=15.9 \%)$ with the levels being approximately 60 times higher than those of NoV GI. In 8 out of 10 replicates, NoV GI could only be detected at levels which were below the LOQ while NoV GI was not detected in one out of the ten replicates. The concentration of $E$. coli in the shellfish flesh was low, represented $12 \%$ of the total coliforms and had a high variability between the replicate batches $(\mathrm{CV}=128 \%)$.

\subsection{Norovirus and bacterial levels in mussels after 30 days}

After $30 \mathrm{~d}$ (April) all moorings remained in-situ and the mussels $(51.5 \pm 0.2 \mathrm{~mm}, 98.0 \%$ survival) from 11 of 13 sites contained quantifiable levels of NoV GI and GII, both showing a distinct spatial pattern. After $60 \mathrm{~d}$ (May) only 2 and 3 of 12 remaining moorings provided samples with NoV levels above the method limit of quantification for GI and GII, respectively. As the summer

progressed, NoV remained mostly below quantifiable levels. We therefore present the spatial pattern derived for the initial $30 \mathrm{~d}$ deployment period.

After being deployed around the wastewater outfall for $30 \mathrm{~d}$, NoV GI levels significantly increased from the $T_{0}$ baseline value of $52 \pm 6 \mathrm{gc} \mathrm{g}^{-1}$ to $1990 \pm 619 \mathrm{gc} \mathrm{g}^{-1}$ when averaged across all sites $(P<0.05)$. In contrast, across the sampling array, mean NoV GII levels decreased slightly from the $T_{0}$ baseline value of $3311 \pm 167 \mathrm{gc} \mathrm{g}^{-1}$ to $1990 \pm 851 \mathrm{gc} \mathrm{g}^{-1}$ after $30 \mathrm{~d}$, although this was not statistically significant due to the variability across samples. If the point directly above the outfall is omitted, the levels of GI and GII in the mussels were highly correlated across all the samples $\left(r^{2}=\right.$ 
situation. Overall, both NoV GI and GII showed much greater dispersion to the East and West and symmetry about the outfall. NoV GI decreased with distance in all directions from the outfall (7825 $\mathrm{gc} \mathrm{g}^{-1}$ ), however, for NoV GII, the highest contamination levels (9958 $\mathrm{gc} \mathrm{g}^{-1}$ ) were observed at the most Easterly sample point, $2 \mathrm{~km}$ to the East of the outfall $\left(7954 \mathrm{gc} \mathrm{g}^{-1}\right)$. For both NoV genogroups, levels in the shellfish declined more rapidly to the North and South of the outfall than to the East and West. However, significantly higher NoV contamination was observed South of the outfall (onshore) than to the North. The mean concentration for three adjacent sites South of the outfall $(\Sigma$ GI + GII $2255 \pm 154 \mathrm{gc} \mathrm{g}^{-1}$ ) was significantly higher than for three adjacent sites to the North ( $\Sigma$ GI + GII 329 $\pm 84 \mathrm{gc} \mathrm{g}^{-1}$ ) for both GI and GII (t-test $P=0.005$ and $P=0.019$ respectively).

E. coli contamination of shellfish flesh increased in the samples collected directly over the outfall (approximately 3-fold from the $T_{0}$ value of $400 \pm 163$ to $1167 \pm 166 \mathrm{CFU} 100 \mathrm{~g}^{-1}$ ) and decreased to undetectable levels at 5 sites (Fig. 2). The total coliform content of the mussels increased approximately 6-fold when placed directly over the outfall (3400 \pm 670 at $T_{0}$ to $20,833 \pm 1764 \mathrm{CFU}$ $100 \mathrm{~g}^{-1}$ at $30 \mathrm{~d}$ ) and decreased at all but four sites where there was no significant change. Total coliforms and $E$. coli concentrations were also highly correlated across all sites $\left(r^{2}=0.82 ; P<0.001\right)$. For E. coli and coliforms the spatial contamination pattern around the outfall were slightly different. E. coli was detected at highest levels directly over the outfall, but was not detected within the transect to the West nor the North of the outfall, being skewed East and towards the shore. Total coliforms were also detected at highest levels over the outfall, and also showed a skewed distribution East and slightly towards shore, but were detected at all sites. Correlation between total coliform and total NoV $(\Sigma \mathrm{GI}+\mathrm{GII})$ concentrations was weakly significant $\left(r^{2}=0.43 ; P<0.01\right)$. E. coli did not correlate significantly with NoV levels $\left(r^{2}=0.28, P>0.05\right)$.

\subsection{Comparison of experimental results with hydrodynamic model predictions}

Our data failed the assumptions for regression analysis, but Spearman's rank-order correlation coefficients $\left(r_{\mathrm{s}}\right)$ and their significance were calculated between the model prediction for water 
concentrations and experimentally derived levels of $\mathrm{NoV}, E$. coli and total coliforms in shellfish tissue (Table 2). Both NoV GI and GII showed strong correlations with model predictions, which were highly significant. However, neither E. coli nor total coliforms showed any significant correlation with the model predictions. Experimentally-derived levels found in the shellfish tissues were plotted and compared with predicted relative concentrations according to the model for North-South and West-East transects passing over the outfall (Fig. 3). The relative values predicted by the model were normalized to the values found directly above the outfall for each measure. Overall, NoV (GI and GII) results showed very good agreement with the model simulations. To the West of the outfall, and particularly for GII, predictions and experimentally-derived levels matched very closely while to the East there were some differences. Slightly higher levels than those predicted by the model were also found $1 \mathrm{~km}$ to the South of the outfall for both NoV GI and GII. The model overestimated the relative levels for E. coli and total coliforms both to the East and to the West of the outfall (Fig. 3). However, higher levels than the model would predict were found to the South (onshore) of the outfall.

\section{Discussion}

\subsection{Spatial patterns of NoV accumulation in mussels}

This field-based study investigated the spatial accumulation of NoV and FIB around an offshore coastal discharge originating from a large municipal WWTP. The low levels of NoV GI in the biosentinel mussels used to stock the experiment allowed us to obtain clear spatial patterns of contamination around the outfall after a $30 \mathrm{~d}$ period. A period of $23 \mathrm{~d}$ has been considered sufficient for transplanted oysters to stabilize and represent in situ background levels (Campos et al., 2015). Higher initial levels of NoV GII in the mussels used to stock the experiment were observed to either increase at some sites, or decline at others, revealing a similar pattern. This suggests that the levels after $30 \mathrm{~d}$ are representative of contamination in situ, depending upon relative exposure to the effluent plume during a peak period of NoV community incidence (PHE 2016). Furthermore, spatial contamination patterns for GI and GII NoV were highly correlated. A peak NoV GII concentration 
observed $2 \mathrm{~km}$ East of the outfall could indicate a secondary contamination source (e.g. River Clwyd) impacting this location. The most contaminated sites by either NoV genogroup all occupy the EastWest transect through the center point of the array, over the outfall, and concentrations declined steeply with distance both to the North and South. This finding was expected due to the reversing East- and Westerly currents during ebb and flow, and is in visual agreement with hydrodynamic model predictions for the same sewage discharge plume. It coincides with a strong correlation between model predictions and experimentally-derived levels for both NoV GI and GII. In the future, we expect that this type of correlation can be used to predict potential NoV levels using summed or average effluent dilutions as predicted by hydrodynamic models. This would greatly help the generation of tools for determining shellfish production exclusion zones around other outfalls for which a hydrodynamic model is available (e.g. a zone where mussels may be expected to accumulate $>1000 \mathrm{NoV} \mathrm{gc} \mathrm{g}^{-1}$ ). Such an approach would have clear benefits over arbitrary proximity-based zoning as detailed by Fitzgerald (2015) and Silva et al. (2011).

\subsection{NoV GI and GII accumulation ratios in mussels}

Baseline measurements made at the start of the experiment $\left(T_{0}\right)$ showed a much greater abundance of NoV GII relative to the amount of NoV GI present in the mussels (GI:GII ratio $=0.016$ $\pm 0.001)$. This ratio is highly consistent with NoV outbreaks and presence within the wider community measured during the same time (monthly Mar-Apr mean GI:GII ratio $=0.016 \pm 0.005$; mainly associated with GII.4; PHE, 2016). Interestingly, however, after being deployed around the outfall for $30 \mathrm{~d}$, levels of GI in mussels markedly increased becoming similar to NoV GII levels across all samples (GI:GII ratio $=0.98 \pm 0.15$ ). Due to access issues, effluent samples of wastewater were not available for analysis. However, factors known to affect the ratio of GI:GII ratio in wastewater and shellfish include: (i) prevalence of GI:GII infection in the community, (ii) their differential resistance to water treatment processes, (iii) differences in biotic and abiotic degradation in seawater, and (iv) differential accumulation and subsequent loss from shellfish tissues. The ratio 
of NoV GI:GII ratio has remained relatively stable in the human population over a long time (PHE, 2016). Although there is a possibility of a high community prevalence of NoV GI infection during the study period, there is strong evidence to suggest that the other three factors contributed to the preferential accumulation of GI in our shellfish. Firstly, Da Silva et al. (2007) and Rajko-Nenow et al. (2013) both present data to suggest that NoV GI is more resistant to WWTP processes than NoV GII. Secondly, in terms of environmental persistence, NoV GI may be more stable in the water environment than GII (Lysén et al., 2009). Thirdly, it has been shown that NoV GI may accumulate more efficiently and strongly in oysters and mussels than NoV GII (Langlet et al., 2015; Ventrone et al., 2013). In addition, NoV GII accumulates at sites in shellfish where it might be more susceptible to being destroyed (Maalouf et al., 2010; Maalouf et al., 2011). Lastly, a depuration study by Polo et al. (2014) showed that GI showed greater retention in mussel tissue when exposed to clean seawater. Taken together, this also correlates with the finding that NoV GI is more frequently encountered in shellfish-related NoV outbreaks (LeGuyader et al., 2012). Low levels (below LOQ) of both GI and GII in most samples collected in and after May (data not presented) is not surprising given the widely recognized seasonality of NoV incidence in the community and detection in shellfish (Lowther et al., 2012a).

\subsection{Spatial patterns of faecal indicator bacteria accumulation in mussels}

In contrast to NoV, no significant agreement was found between the measured concentrations of $E$. coli or coliforms in mussels and the modelled effluent plume exposure. Furthermore, whilst $E$. coli correlated with total coliforms and NoV GI correlated strongly with NoV GII, no significant correlation was found between E. coli and NoV. Indeed, NoV GI and GII were detected in mussels at very high concentrations at sites at which $E$. coli was not detected, notably to the West of the outfall. We are aware that the tidal current was flowing to the East at the time of sampling and therefore mussels to the West are likely to have been less recently exposed to the effluent plume. This is consistent with evidence that FIB are indicators of recent faecal contamination but NoV can persist 
351 for weeks in shellfish tissue (Johne et al., 2011). The water is deeper to the West of the outfall and a 352 differential effect of water depth upon NoV / FIB behavior is also plausible given potential association 353 with particles and related sedimentation / resuspension phenomena. Importantly, all cages were 354 suspended at $1 \mathrm{~m}$ below the surface rather than on the seabed. Conversely, FIB were detected at sites 355 at which NoV was not detected, with the distribution of FIB being somewhat more skewed towards 356 the shore. We hypothesize that secondary non-point sources, which may be of animal origin, affect 357 this pattern. Therefore, this study suggests that FIB indicate the presence of faecal contamination but 358 may not accurately reflect persistent contamination by viral pathogens associated with human-sewage 359 effluent.

\subsection{Implications for human health}

The regulations for the commercial sale of shellfish in Europe are solely based on concentrations of E. coli in shellfish flesh. All the mussels in this study recovered from around the

NoV from our shellfish (Polo et al., 2014; Sharp et al., 2016).

\section{Conclusions} result in a significant environmental release of NoV during outbreaks in the human population. This can result in high levels of NoV accumulation in shellfish. Investment in wastewater treatment technology could reduce the level of risk in shellfisheries and recreational waters impacted by sewage discharges. 
2. Mussels with intrinsically low NoV loads can be used as effective bio-sentinels for NoV

pollution in marine waters. As viruses appear to be more persistent in shellfish tissue than some FIB, they may provide a more integrated pollution signal. It is also likely that they can be used to simultaneously evaluate the prevalence of a wide range of human pathogenic viruses in marine waters (Bagordo et al., 2013; Diez-Valcarce et al., 2012). It should be noted, however, that a reliance on NoV alone may provide a poor indicator of other viral pathogens and we recommend the introduction of multi-viral standards for evaluating the potential contamination of recreational waters and shellfish harvesting areas.

3. It is clear that current shellfish hygiene regulations based on E. coli alone are inadequate to protect the human population from consuming shellfish contaminated with high loads of viral pathogens. The mussels recovered here contained NoV levels up to $1.6 \times 10^{4} \mathrm{gc} \mathrm{g}^{-1}$, while in comparison, the human infective dose for NoV is very low ( $\geq 18$ viral particles; Hall, 2012). While we cannot confirm that all the NoV contained in our mussels remained infective to humans, from a risk assessment perspective it is safest to assume that there is some infection potential. Further, there is recent evidence to show that the amount of genome copies detected in shellfish is generally proportional to risk (Lowther et al., 2012b). While adequate cooking may eliminate the risk of contracting $\mathrm{NoV}$, there are many instances where the product is eaten raw or partially cooked or where cross contamination can occur during food preparation (Flannery et al., 2014). We conclude therefore that viral standards are required for shellfish destined for human consumption.

4. Methods for the quantitative recovery of viruses from marine waters have improved but water samples can still provide only snapshots of information from potentially complex tidal systems.

Their low abundance and ephemeral nature also limits their ability to assess risk. This is limiting the introduction of viral surveillance measures for bathing waters. Mussel biosentinels therefore offer a cost-effective way of measuring microbiological pollution, integrated over a time period, particularly in recreational waters. In this scenario, mussels could be easily deployed on buoys at the perimeter of the bathing zone and sent for routine analysis. 

harvesting exclusion zones, especially where contamination arises from point source discharges, as per this study. However, more work is needed to validate and improve these models from a viral risk 405 assessment perspective. Part of this needs to include validation for a range of viruses including those models.

\section{Acknowledgements}

This study was funded by Bangor Mussel Producers, Welsh Water and the European Social

Fund via the KESS Scholarships programme. We would like to thank Richard Dannatt and Samantha Mullan (Intertek) for assistance with model interpretation and Paul Henderson, Fergus O'Brien and Roger Cragg (Welsh Water Ltd) for outfall information, flow data and permission to use the model. We also thank Ian Harris (Bangor University) for help with the GIS and Gwynne Parry-Jones (Bangor University) and Trevor Jones (Bangor Mussel Producers) for boat time and skippering.

\section{References}

Anon, 2004. Corrigendum to regulation (EC) No 854/2004 of the European Parliament and of the Council of 29 April 2004 laying down specific rules for the organisation of official controls on products of animal origin intended for human consumption. Official Journal of the European Union L226, 83-127.

Anon, 2013. ISO TS 15216-1:2013 Microbiology of food and animal feed: Horizontal method for determination of hepatitis A virus and norovirus in food using real-time RT-PCR, Part 1: 
Method for quantification International Organization for Standardization. International Organization for Standardization, Geneva, Switzerland.

\section{0}

Asahina, A.Y., Lu, Y., Wu, C., Fujioka, R.S., Loh, P.C., 2009. Potential biosentinels of human waste in marine coastal waters: Bioaccumulation of human noroviruses and enteroviruses from sewage-polluted waters by indigenous mollusks. J. Virol. Meth. 158, 46-50.

Babu, M.T., Vethamony, P., Desa, E., 2005. Modelling tide-driven currents and residual eddies in the Gulf of Kachchh and their seasonal variability: A marine environmental planning perspective. Ecol. Model. 184, 299-312.

Bagordo, F., Grassi, T., Idolo, A., Serio, F., Gabutti, G., De Donno, A., 2013. Rotavirus occurrence in shellfish with low levels of E. coli. Food Environ. Virol. 5, 169-175.

Calgua, B., Mengewein, A., Grunert, A., Boffil-Mas, S., Clemente-Casares, P., Hundesa, A., WynJones, A.P., López-Pila, J.M., Girones, R. 2008. Development and application of a one-step low cost procedure to concentrate viruses from seawater samples. J. Virol. Meth. 153, 79-83.

Campos, C.J.A., Acornley, R., Morgan, O.C., Kershaw, S., 2013a. Trends in the levels of Escherichia coli in commercially harvested bivalve shellfish from England and Wales, 1999-2008. Mar. Pollut. Bull. 67, 223-227.

Campos, C.J.A., Kershaw, S.R., Lee, R.J., 2013b. Environmental influences on faecal indicator organisms in coastal waters and their accumulation in bivalve shellfish Estuar. Coast. 36, 834853.

Campos, C.J.A., Avant, J., Gustar, N., Lowther, J., Powell, A., Stockley, L., Lees, D.N., 2015. Fate of Human Noroviruses in Shellfish and Water Impacted by Frequent Sewage Pollution Events. Environ. Sci. Technol. 49, 8377-8385

Cormier, J., Gutierrez, M., Goodridge, L., Janes, M., 2014. Concentration of enteric virus indicator from seawater using granular activated carbon. J. Virol. Meth. 196, 212-218.

Cormier, J., Janes, M., 2016. Concentration and detection of hepatitis A virus and its indicator from artificial seawater using zeolite. J. Virol. Meth. 235, 1-8. 
455 Clements, K., Giménez, L., Jones, D.L., Wilson, J., Malham, S.K., 2013. Epizoic barnacles act as 456 pathogen reservoirs on shellfish beds. J. Shellfish Res. 32, 1-6.

457 Dancer, D., Rangdale, R.E., Lowther, J.A., Lees, D.N., 2010. Human Norovirus RNA persists in 458 seawater under simulated winter conditions but does not bioaccumulate efficiently in Pacific 459 Oysters (Crassostrea gigas). J. Food Protec. 73, 2123-2127.

460 Davies, S., Mirfenderesk, H., Tomlinson, R., Szylkarski, S., 2009. Hydrodynamic, water quality and 461 sediment transport modeling of estuarine and coastal waters on the Gold Coast Australia. J. Coast. Res. 56, 937-941.

De Donno, A. Grassi, T., Bagordo, F., Idolo, A., Serio, F., Gabutti, G., 2012. Detection of viruses in coastal seawater using Mytilus Galloprovincialis as an accumulation matrix. Food Environ. Virol. 4, 81-88.

Da Silva, A.K., Le Saux, J.C., Parnaudeau, S., Pommepuy, M., Elimelech, M., Le Guyad, F.S., 2007. Evaluation of removal of noroviruses during wastewater treatment, using real-time Reverse Transcription-PCR: Different behaviors of genogroups I and II. Appl. Environ. Microbiol. 73, 7891-7897.

DHI, 2003. MIKE 21: Coastal Hydraulics and Oceanography, Hydrodynamic Module. Scientific Documentation. DHI Software, Hørsholm, Denmark.

DHI, 2011. MIKE 21 \& MIKE 3 FLOW MODEL FM Hydrodynamic and Transport Module Scientific Documentation. DHI Software, Hørsholm, Denmark.

Diez-Valcarce, M., Kokkinos, P., Soderberg, K., Bouwknegt, M., Willems, K., de Roda-Husman, A., von Bonsdorff, C.H., Bellou, M., Hernandez, M. Maunula, L., Vantarakis, A., RodríguezLázaro, D., 2012. Occurrence of human enteric viruses in commercial mussels at retail level in three European countries. Food Environ. Virol. 4, 73-80. 
Dunn, R.J.K., Zigic, S., Shiell, G.R., 2014. Modelling the dispersion of treated wastewater in a shallow coastal wind-driven environment, Geographe Bay, Western Australia: implications for environmental management. Environ. Monit. Assess. 186, 6107-6125.

Ekebjærg, L., Justesenu, P., 1991. An explicit scheme for advection-diffusion modelling in two dimensions. Comp. Meth. Appl. Mech. Engineer. 88, 287-297.

EFSA Panel on Biological Hazards, 2012. Scientific Opinion on Norovirus (NoV) in oysters: methods, limits and control options, Available at: www.efsa.europa.eu/efsajournal.

EU, 2006. Directive 2006/113/EC of the European Parliament and of the council of $12^{\text {th }}$ December 2006 on the quality required of shellfish waters. European Union, Brussels, Belgium.

Ferguson, C.M., Coote, B.G., Ashbolt, N.J., Stevenson, I.M., 1996 Relationships between indicators, pathogens and water quality in an estuarine system. Water Res. 30, 2045-2054.

Fitzgerald, A., 2015. Review of approaches for establishing exclusion zones around sewage discharge points; Desk study to inform consideration of the possible introduction of exclusion zones as a control for norovirus in oysters. FS513404 Aquatic Water Services Limited. Wadebridge, UK.

Flannery, J. Keaveney, S., Rajko-Nenow, P., O'Flaherty, V., Doré, W., 2012. Concentration of norovirus during wastewater treatment and its impact on oyster contamination. Appl. Environ. Microbiol. 78, 3400-3406.

Flannery, J., Rajko-Nenow, P., Winterbourn, J.B., Malham, S.K., Jones, D.L., 2014. Effectiveness of cooking to reduce Norovirus and infectious F-specific RNA bacteriophage concentrations in Mytilus edulis. J. Appl. Microbiol. 117, 564-571.

Fleming, L.E., Broad, K., Clement, A., Dewailly, E., Elmir, S., Knap, A., Pomponi, S.A., Smith, S., Gabriele, H.S., Walsh, P., 2006. Oceans and human health: Emerging public health risks in the marine environment. Mar. Pollut. Bull. 53, 545-560. 
Fong, T.T., and Lipp, E.K., 2005. Enteric viruses of humans and animals in aquatic environments: health risks, detection, and potential water quality assessment tools. Microbiol. Molec. Biol. Rev. 69, 357-371.

Gourmelon, M., Lazure, P., Hervio-Heath D., Le Saux, J.C., Caprais, M.P., Le Guyader, F.S., Catherine, M., Pommepuy, M., 2010. Microbial modelling in coastal environments and early warning systems: useful tools to limit shellfish microbial contamination. pp 297-318. In Safe Management of Shellfish and Harvest Waters (Eds. Rees, G., Pond, K., Kay, D., Bartram, J., Santo Domingo, J.), IWA Publishing, London, UK.

Griffin, D.W. Gibson, C.J., Lipp, E.K., Riley, K., Paul, J.H., Rose, JB., 1999. Detection of viral pathogens by reverse transcriptase PCR and of microbial indicators by standard methods in the canals of the Florida Keys. Appl. Environ. Microbiol. 65, 4118-4125.

Griffin, D.W., Lipp, E.K., McLaughlin, M.R., Rose, J.B., 2001. Marine recreation and public health microbiology: Quest for the ideal indicator. Bioscience 51, 817-825.

Hall, A.J., 2012. Noroviruses: The perfect human pathogens? J. Infect. Dis. 205, 1622-1624.

Hammerstein, H.C., Work, P.A., Frischer, M.E., 2015. Bacteriophage tracer for fecal contamination sources in coastal waters. Water Qual. Expos. Health 7, 15-26.

Johne, R., Pund, R.P., Schrader, C., 2011. Experimental accumulation and persistence of norovirus, feline calicivirus and rotavirus in blue mussels (Mytilus edulis). Arch. Lebensmittelhyg. 62, $129-135$.

Kaas, L., Gourinat, A., Urbès, F., Langlet, J. 2016. A 1-year study on the detection of human enteric viruses in new Caledonia. Food Environ. Virol. 8, 46-56.

Katayama, H., Shimasaki, A., Ohgaki, S., 2002. Development of a virus concentration method and its application to detection of enterovirus and Norwalk virus from coastal seawater. Appl. Environ. Microbiol. 68, 1033-1039.

Langlet, J., Kaas, L., Greening, G., 2015.Binding-based RT-qPCR assay to assess binding patterns of noroviruses to shellfish. Food Environ. Microbiol. 7, 88-95. 
Le Guyader, F.S., Atmar, R.L., Le Pendu, J., 2012. Transmission of viruses through shellfish: when specific ligands come into play. Curr. Opin. Virol. 2, 103-110.

Lees, D., 2000. Viruses and bivalve shellfish. Int. J. Food Microbiol. 59, 81-116.

Lees, D. and CEN WG6 TAG4, 2010. International standardisation of a method for detection of human pathogenic viruses in molluscan shellfish. Food Environ. Virol. 2, 146-155.

Lowther, J.A., Gustar, N.E., Powell, A.L., Hartnell, R.E., Lees, D.N., 2012a. Two-year systematic study to assess norovirus contamination in oysters from commercial harvesting areas in the United Kingdom. Appl. Environ. Microbiol. 78, 5812-5817.

Lowther, J.A. Gustar, N.E., Hartnell, R.E., Lees, D.N., 2012b. Comparison of norovirus RNA levels in outbreak-related oysters with background environmental levels. J. Food Protec. 75, 389393.

Lysén, M., Thorhagen, M., Brytting, M., Hjertqvist, M., Andersson, Y., Hedlund, K.O., 2009. Genetic diversity among food-borne and waterborne norovirus strains causing outbreaks in Sweden. J. Clin. Microbiol. 47, 2411-2418.

Maalouf, H., Zakhour, M., Le Pendu, J., Le Saux, J.C., Atmar, R.L., Le Guyader, F.S., 2010. Distribution in tissue and seasonal variation of norovirus genogroup I and II ligands in oysters. Appl. Environ. Microbiol. 76, 5621-5630.

Maalouf, H., Schaeffer, J., Parnaudeau, S., Le Pendu, J., Atmar, R.L., Crawford, S.E., Le Guyader, F.S., 2011. Strain-dependent norovirus bioaccumulation in oysters. Appl. Environ. Microbiol. 77, 3189-3196.

Majori, L., Campello, C., D'Alessandro, F., Berzero, R., Bovo, F., Guarineri, G., 1984. Vibrio cholerae non-O1 e Vibrio parahaemolyticus in acque e mitili della Laguna di Venezia: studio ecologico e relativi problem igienico-sanitari. Ig. Mod. 82, 436-455.

Malham, S.K., Rajko-Nenow, P., Howlett, E., Tuson, K.E., Perkins, T.L. Pallett, D.W., Wang, H., Jago, C.F., Jones, D.L., McDonald, J.E., 2014. The interaction of human microbial pathogens, 
particulate material and nutrients in estuarine environments and their impacts on recreational and shellfish waters. Environ. Sci. Process. Impact. 16, 2145-2155.

Matthiessen, P., Law, R.J., 2002. Contaminants and their effects on estuarine and coastal organisms in the United Kingdom in the late twentieth century. Environ. Pollut. 120, 739-757.

Moore, M.N., Depledge, M.H., Fleming, L., Hess, P., Lees, D., Leonard, P., Madsen, L., Owen, R., Pirlet, H., Seys, J., Vasconcelos, V., Viarengo, A., Marine Board-ESF Working Group on Oceans and Human Health, 2013. Oceans and Human Health (OHH): A European perspective from the Marine Board of the European Science Foundation (Marine Board-ESF). Microb. Ecol. 65, 889-900.

Muhammetoglu, A. Yalcin, O.B., Ozcan, T., 2012. Prediction of wastewater dilution and indicator bacteria concentrations for marine outfall systems. Mar. Environ. Res. 78 53-63.

Nenonen, N.P. Hannoun, C., Horal, P., Hernroth, B., Bergström, T., 2008. Tracing of norovirus outbreak strains in mussels collected near sewage effluents. Appl. Environ. Microbiol. 74, 2544-2549.

Nordgren, J. Matussek, A., Mattsson, A., Svensson, L., Lindgren, P.E., 2009. Prevalence of norovirus and factors influencing virus concentrations during one year in a full-scale wastewater treatment plant. Water Res. 43, 1117-1125.

Oliveira, J., Cunha, A., Castilho, F., Romalde, J,L., Pereira, M.J., 2011. Microbial contamination and purification of bivalve shellfish: Crucial aspects in monitoring and future perspectives - A minireview. Food Control 22, 805-816.

Pancorbo, O.C., Barnhart, H.M., 1992. Microbial pathogens and indicators in estuarine environments and shellfish - critical need for better indicator(s) of human-specific fecal pollution. J. Environ. Health 54, 57-63.

Paraskevas, P.A., Giokas, D.L., Lekkas, T.D., 2002. Wastewater management in coastal urban areas: the case of Greece. Water Sci. Technol. 46, 177-186. 
PHE, 2016. PHE Weekly national norovirus and rotavirus report: Summary of surveillance of norovirus and rotavirus, $17^{\text {th }}$ March 2016. Public Health England, London, UK.

Polo, D., Alvarez, C., Diez, J., Darriba, S., Longa, A., Romalde, J.L., 2014. Viral elimination during commercial depuration of shellfish. Food Control 43, 206-212.

Rajko-Nenow, P. Waters, A., Keaveney, S., Flannery, J., Tuite, G., Coughlan, S., O'Flaherty, V., Doré, W., 2013. Norovirus genotypes present in oyster and effluent from a wastewater treatment plant during the seasonal peak of infections in Ireland, 2010. Appl. Environ. Microbiol. 79, 2578-2587

Riou, P., Le Saux, J.C., Dumas, F., Caprais, M.P., Le Guyader, S.F., Pommepuy, M., 2007. Microbial impact of small tributaries on water and shellfish quality in shallow coastal areas. Water Res. 41, 2774-2786.

Rodríguez, R.A., Thie, L., Gibbons, C.D., Sobsey, M.D., 2012. Reducing the effects of environmental inhibition in quantitative real-time PCR detection of adenovirus and norovirus in recreational seawaters. J. Virol. Meth. 181, 43-50.

Siegle, E., Huntley, D.A., Davidson, M.A., 2007. Coupling video imaging and numerical modelling for the study of inlet morphodynamics. Mar. Geol. 236, 143-163.

Silva, C., Ferreira, J.G., Bricker, S.B., DelValls, T.A., Martin-Diaz, M.L., Yanez, E., 2011. Site selection for shellfish aquaculture by means of GIS and farm-scale models, with an emphasis on data-poor environments. Aquaculture 318, 444-457.

Stapleton, C.M., Wyer, M.D., Crowther, J., McDonald, A.T., Kay, D., Greaves, J., Wither, A., Watkins, J., Francis, C., Humphrey, N., 2008. Quantitative catchment profiling to apportion faecal indicator organism budgets for the Ribble system, the UK's sentinel drainage basin for Water Framework Directive research. J. Environ. Manage. 87, 535-550.

Ventrone, I., Schaeffer, J., Ollivier, J., Parnaudeau, S., Pepe, T., Le Pendu, J., Le Guyader, F.S., 2013. Chronic or accidental exposure of oysters to norovirus: is there any difference in contamination? J. Food Protec. 76, 505-509. 
604 Williams, J.J., Esteves, L.S., Conduche, T., Barber, P., Tindle, A., 2014. Using combined modelling 605 approaches to improve coastal defence design: a case study at Hopton, UK. J. Coast. Res. 70, 606 $18-23$. 


\section{Figure legends}

Fig. 1. Map showing the location of the municipal wastewater treatment plant and its offshore discharge point around which an array of biosentinels cages containing mussels were placed in a 1 km diamond grid.

Fig 2. Experimentally measured and modelled concentrations of microbiological contaminants in water and biosentinel shellfish in response to an offshore discharge of wastewater. Panel A shows the predicted plume of a conservative microbiological pollutant released from the offshore discharge point into the coastal water. Model simulations were undertaken with MIKE21. Panels B-E show experimentally-derived spatial patterns of NoV GI (Panel B), NoV GII (Panel C), E. coli (Panel D) and total coliforms (Panel E). The maps for Panels B-E were derived from the amount of indictor organism accumulated in the mussel biosentinels. For NoV GI and GII, contours represent detectable genome copies $\mathrm{g}^{-1}$ of digestive gland. Total coliforms and E. coli contours represent CFU $100 \mathrm{~g}^{-1}$ shellfish flesh and intravalvular fluid. The scale of all Panels is the same.

Fig. 3. Direct comparison of experimentally measured and modelled concentrations of four microbiological indicators in shellfish in response to an offshore discharge of wastewater. The graphs represent either the West-East or North-South transects shown in Figure 1. Bars represent the experimental data and dotted lines show the predicted relative concentrations extracted from the hydrodynamic model and normalized to the experimentally-derived value for the sampling point located directly over the outfall. 